\title{
Estimation of Minimum Inhibitory Concentration (MIC) and Minimum Bactericidal Concentration (MBC) of Cell-Free Extracts of Bifidobacterium Species Against Methicillin-Resistant Staphylococcus aureus in vitro
}

\author{
Zainab Nashaat AL-Saadi \\ Department of Biology, College of Science, University of Wasit, Iraq
}

Email address:

hareer1976@gmail.com

To cite this article:

Zainab Nashaat AL-Saadi'. Estimation of Minimum Inhibitory Concentration (MIC) and Minimum Bactericidal Concentration (MBC) of Cell-Free Extracts of Bifidobacterium Species Against Methicillin-Resistant Staphylococcus aureus in vitro. American Journal of Biomedical and Life Sciences. Vol. 4, No. 5, 2016, pp. 75-80. doi: 10.11648/j.ajbls.20160405.12

Received: August 19, 2016; Accepted: October 9, 2016; Published: October 31, 2016

\begin{abstract}
The aim of this study was to examine if extract of bifidobacteria, a major species of the human colonic microflora participates in the barrier effect against enteropathogens by developing antimicrobial activity against virulent bacteria. Six human bifidobacteria strains were isolated from infant stools. They were characterized and identified through physiological, biochemical tests and API 20 A test system. The isolates belonged to the three species: B. breve, B.longum and B.infantis. The cell extracts of the isolates were examined for antimicrobial activity by determination of minimum inhibitory concentration (MIC) and minimum bactericidal concentration (MBC). For this purpose, the methicillin-resistant $S$. aureus (MRSA) was chosen as an indicator. MRSA treated with cell-free supernatants (CFS) from bifidobacteria were examined. All the Bifidobacterium isolates used have been identified as novel probiotics with a greater ability to survive at low $\mathrm{pH}$ and high concentrations of bile salt in vitro. $0.5 \mathrm{McFarland}$ standard $\left(10^{8} \mathrm{CFU} / \mathrm{ml}\right)$ of a confirmed MRSA strain was challenged with the CFS strains by employing the tube dilution method and subculture on MRS agar assays. The cell-free supernatants of the 6 LAB strains exhibited MIC values between $50 \mu \mathrm{l} / \mathrm{ml}$ and $200 \mu \mathrm{l} / \mathrm{ml}$. Only two CFS of bifidobacteria (b3 and b 4) had no MIC and $\mathrm{MBC}$ values with the concentrations under the current study. The b1, BL and BI strains showed highest antibacterial activity by MIC value with 100 conc. and by MBC value with 150 conc. Increased concentration levels of the cell-free extract (CFE) correlated with a decrease in MRSA viability. MRS broth medium (control) showed a high growth rate of MRSA without CFE.These results may provide a basis for alternative therapies for the treatment of MRSA superbug.
\end{abstract}

Keywords: Bifidobacterium Spp., MBC, MIC, MRSA

\section{Introduction}

The probiotic micro-organisms are single-celled, nonpathogenic organisms which do not promote or cause disease. Most commonly used probiotic supplements contain the species of Lactobacillus and Bifidobacterium and they are part of normal human intestinal microbiota [1]. The World Health Organization deemed probiotics to be the next-most important immune defense system when commonly prescribed antibiotics are rendered useless by antibiotic resistance [2].

Bifidobacterium breve is primarily located in human breast milk and the gastrointestinal tract of infant and adult humans, where they are among the first microbial colonizers, passed from the mother to her offspring. $B$. breve exhibits a symbiotic relationship with their host by exploiting their unique metabolic capabilities in order to catabolize certain carbohydrates, such as the oligosaccharides present in human breast milk, that are indigestible by their host [3]. B. breve has not been recorded as the cause of human disease and has been in commercial use as a probiotic since 1976 [4].

Staphylococcus aureus is one of the most important bacterial opportunistic pathogens in humans and the principal nosocomial pathogen worldwide. S.aureus is known for its rapid development of resistance to different antimicrobial 
agents especially its resistance to beta-lactam antibiotics (socalled methicillin-resistant S.aureus, MRSA, a multidrugresistant microorganism). S.aureus can become MRSA by the acquisition of the mecA gene, which encodes the penicillin binding protein (PBP2a) with a low affinity for b-lactams [5]. The PBP2a-producing MRSA strain is resistant not only to methicillin, oxacillin and nafcillin but also to all other blactam antibiotics including cephalosporins [6].

Probiotics must survive gastric and bile acids in order to reach the intestinal tract. Once there, they must be capable of adhering to human epithelial cells. Lastly, they prevent colonization by pathogenic bacteria, either by competitive exclusion or synthesis of antimicrobial substances [6]. Beneficial effects conferred by $B$. breve, including the inhibition of gram-negative and gram-positive pathogenic bacteria, were described by [7] and reported that B.breve had a specific antagonistic effect against MRSA.

Probiotics have been shown to suppress pathogen growth through the release of a variety of antimicrobial factors like defensins, bacteriocins, hydrogen peroxide, nitric oxide, and short-chain fatty acids (SCFA), such as lactic and acetic acids, which reduce the $\mathrm{pH}$ of the lumen [8].

A high percentage of hospital-acquired infections are caused by highly resistant bacteria, such as methicillinresistant Staphylococcus aureus (MRSA). People with MRSA are estimated to be 64 percent more likely to die than individuals with a non-resistant form of the infection [9].

So that, the purpose of the present study was to determine the antagonistic activity of cell-free extract of $B$. breve against Methicillin-resistant S.aureus (MRSA) superbug and the estimation of the minimum inhibitory concentration and minimum bactericidal concentration.

\section{Materials and Methods}

\subsection{Samples Collection}

\subsubsection{Source of the Pathogenic Isolates}

The target pathogenic bacteria were clinically isolated including (4) isolates of Staphylococcus aureus which were obtained from the microbiology laboratory of AL-Karama teaching hospital in Wasit province. The isolates were diagnosed by using VITEK system (Healthcare, biomerieux) and the growth of the $S$. aureus was confirmed after incubation by observing the colony characteristics under a microscope and by biochemical tests.

\subsubsection{Lactic Acid Bacteria}

Ten fecal samples were collected from infants aged (2-4) weeks and who relied on feeding on breast milk with no trace of any kind of antibiotics during the collection of samples. Models were developed directly in the middle of the sterile liquid MRS-broth [10].

\subsection{Isolation of Bacteria}

The LAB bacteria were isolated as described by described [10]. Stool samples from 10 infants in good health aged 2-4 weeks and with certified breastfeeding. 1 gram of stool sample was taken and placed in the middle of $9 \mathrm{ml}$ of MRS broth ( $\mathrm{pH} \mathrm{6.2)} \mathrm{and} \mathrm{was} \mathrm{transported} \mathrm{to} \mathrm{the} \mathrm{laboratory} \mathrm{in} \mathrm{less}$ than 6 hours for the purpose of bacterial examination. A direct smear was performed and incubation was done for 24 hours under anaerobic conditions at a temperature of $37^{\circ} \mathrm{C}$. Subculture was prepared by taking $1 \mathrm{ml}$ from each test tube and added to $9 \mathrm{~mL}$ of MRS-broth and then placed in peptone water and incubated for 24 hours under anaerobic conditions and a temperature of $37^{\circ} \mathrm{C}$. This step was repeated three times for the purpose of purification and activation. $1 \mathrm{ml}$ of each dilution was taken and spread in the middle of MRSNNL-Agar (nalidixic acid $15 \mu / \mathrm{mL}$, neomycin sulphate 100 $\mu \mathrm{g} / \mathrm{mL}$ and lithium chloride $3000 \mu \mathrm{g} / \mathrm{mL}$ ) a special development of Bifidobacterium spp. and then incubated in the presence of $\mathrm{CO}_{2}$ and a temperature of $37^{\circ} \mathrm{m}$ for 48 hours.

\subsection{Diagnosis of Lactic Acid Bacteria Isolates}

The isolates underwent biochemical tests that included: Catalase test, Gelatin liquefaction test, Carbohydrate fermentation test and API 20-A system (biomerieux) for diagnosis of anaerobic bacteria in order to contain the number of confirmatory biochemical tests. Characteristics of isolates were compared with what exists in the [11].

\subsection{Characteristics of Bifidobacterium sp.}

\subsubsection{Growth in the Bottom of the MRS-Broth}

Tubes with MRS broth media included with bacterial colonies were incubated anaerobically at a temperature of $37^{\circ} \mathrm{C}$ for $24-48$ hours, and growth was observed in the sediment at the bottom of the test tube [10].

\subsubsection{Growth at Different Temperatures}

By [12], inoculum in MRS broth tubes containing $1 \%$ newly isolated bacteria were incubated under anaerobic conditions and at different temperatures $\left(15^{\circ}, 37^{\circ}\right.$ and $\left.45^{\circ} \mathrm{C}\right)$ for 3-5 days. The result was considered positive if turbidity was found. [10].

\subsubsection{Test for the Resistance of Bacteria to to Bile Salts}

This test was done according to the procedure described by [13]. Lactic acid bacteria (LAB) grown in MRS broth were centrifuged at a rate of (2000) rpm for (10) minutes and suspended in normal saline; then (1) $\mathrm{ml}$ of the suspension was incubated for (3) hours transported into (9) $\mathrm{ml}$ of phosphate buffered saline containing $1 \%$ bile and incubated for (72) hrs and subcultured on MRS agar and incubated in a candle jar at $37^{\circ} \mathrm{C}$.

\subsubsection{Determination of the Ability of Bifidobacterium to Tolerate Low pH $(\mathrm{pH}=3)$}

This test was done according to [14] and [10]. The bifidobacterium was grown in MRS broth was centrifuged at a rate of (2000) rpm for (10) minutes and suspended in normal saline; then (1) $\mathrm{ml}$ of the suspension was transported into (9) $\mathrm{ml}$ of normal saline $(\mathrm{pH}=6.7)$ and (9) $\mathrm{ml}$ of 
phosphate buffered saline ( $\mathrm{pH}=3$ ) and incubated for (3) h, then subcultured on MRS agar and incubated in a candle jar at $37 \mathrm{C}$ for (48) hrs.

\subsection{Phenotypic Screening for Methicillin-Resistant Staphylococci}

Detection of MRSA was carried out using oxacillin screen agar and cefoxitin disc diffusion test as in our previous study to be published and according to [15].

\subsubsection{Oxacillin Agar Screening Test}

Mueller-Hinton agar (MHA) plates containing $4 \% \mathrm{NaCl}$ and $6 \mu \mathrm{g} / \mathrm{ml}$ of oxacillin (Sigma, USA) were obtained from microbiology laboratory, college of science, Wasit University. Plates were inoculated with $10 \mu \mathrm{L}$ of 0.5 McFarland suspension of the isolate by streaking and incubating at $35^{\circ} \mathrm{C}$ for $24 \mathrm{hrs}$. Petri dishes were observed carefully for any growth. Any growth after $24 \mathrm{~h}$ was considered an oxacillin resistant strain.

\subsubsection{Cefoxitin Disc Diffusion Test}

Four isolates were subjected to cefoxitin disc diffusion test using a $30 \mu \mathrm{g}$ disc (Oxoid). The isolate was adjusted by using $0.5 \mathrm{McF}$ arland standard suspension and lawn culture done on Mueller-Hinton agar plate. Plates were incubated at $37^{\circ} \mathrm{C}$ for $18 \mathrm{~h}$ and the zone diameters were measured. An inhibition zone diameter of $\leq 21 \mathrm{~mm}$ was reported as oxacillin resistant bacteria and a diameter of $\geq 22 \mathrm{~mm}$ was considered as oxacillin sensitive bacteria.

\subsection{Antagonism Activity Assay}

\subsubsection{Cell-Free Extract (CFE) Preparation}

Cell-free extract of all lactic acid bacteria used in this study was prepared according to [10] as follows: Bifidobacterium spp. include (6) strains which were inoculated separately in MRS (De Man Rogosa Sharp) broth as $2 \%$ of broth volume and incubated under anaerobic condition at $37^{\circ} \mathrm{C}$ for $72 \mathrm{~h}$. The culture was then centrifuged at $5000 \mathrm{rpm}$ for $30 \mathrm{~min}$. The Supernatants were sterilized by filtration through $(0.22 \mu \mathrm{m})$ membranes (Millipore filter paper-Swinnex-25).

\subsubsection{Determination of Minimum Inhibitory Concentration of CFEs}

The MIC of CFEs for the test strains was determined according to [15]. One isolate of MRSA $(1 \%)$ of $10^{8} \mathrm{cfu} / \mathrm{ml}$ of fresh culture was inoculated in $10 \mathrm{ml}$ nutrient broth containing filter concentrates of the culture supernatant $(50,100,150,200) \mu \mathrm{l}$ and incubated aerobically at $37^{\circ} \mathrm{C}$ for 24 $\mathrm{h}$ for MIC determination

\subsubsection{Determination of Minimum Bactericidal Concentration of CFEs}

After the serial dilution for every treatment was done, then the bactericidal activity of CFE against MRSA was determined by plating $(0.1 \mathrm{ml})$ for each treatment into Mueller Hinton sterilized petri dishes and then incubated at $37^{\circ} \mathrm{C}$ for $24 \mathrm{~h}$, after incubation, results were recorded and compared with the control treatment ( $0 \%$ of CFE), [15][16]

\section{Results}

\subsection{Isolation and Determination of Lactic Acid Bacteria}

Ten (10) fresh fecal samples were collected in the morning from healthy breastfeeding infants aged (2-4) weeks with good health and with no trace of antibiotic during sample collection time.

The Bifidobacterium appeared under light microscope as gram-positive cocci or rod pleomorphic, non-spore forming, non-filamentous and non-motile. Bifidobacterium colonies appear on MRS agar as entire opaque with or without irregular convex edges. Isolates showed negative results for catalase and gas production tests. They also showed negative results for aerobic growth on nutrient agar. The results of the growth at different temperatures for Bifidobacterium was positive at $\left(35^{\circ} \mathrm{C}-45^{\circ} \mathrm{C}\right)$ and the result was negative for growth at thermal grades of $15^{\circ} \mathrm{C}$ and $25^{\circ} \mathrm{C}$. All isolates (b1, b2, b3, b4, BL and BI) showed growth at the bottom of the test tube as deposits in the MRS-broth (Table 1). The API 20 biochemical confirmatory diagnosis for the isolates provides evidence for the purity of isolation. Four (4) of the total isolates belong to $B$. berve species while 2 of them belong to B. longum (BL) and B. infantis (BI ) with (76 and 88.6)\% identification percentages respectively as shown in Table 2 .

Table 1. Result of Biochemical and physiological properties of B.breve.

\begin{tabular}{ll}
\hline Test & Result \\
\hline Gram staining & + ve \\
Catalase & - ve \\
Growth on nutrient agar aerobically & - ve \\
Growth on bottom on MRS broth & + ve \\
Growth on 5 and 15C & - ve \\
Growth on 35 and 45 C & + ve \\
Gas production & $-v e$ \\
\hline
\end{tabular}

Table 2. Identification of examined strains with API 20A system.

\begin{tabular}{lll}
\hline \multirow{2}{*}{ Strain } & Identification with API 20A & \\
\cline { 2 - 3 } & Identification /other possibility & $\begin{array}{l}\text { Percentages of } \\
\text { identification }\end{array}$ \\
\hline (b1) & B.breve & $97.3 \%$ \\
(b2) & B.breve & $99 \%$ \\
(b3) & B.breve & $96.9 \%$ \\
(b4) & B.breve & $99.9 \%$ \\
(BL) & Bifidobacterium longum/B.infant & $76 \%$ \\
(BI) & Bifidobacterium infant/B.longum & $88.6 \%$ \\
\hline
\end{tabular}

\subsection{Characteristics of Bifidobacterium Spp. Strains as Probiotics}

Ability to tolerate bile salts and low $\mathrm{pH}(\mathrm{pH}=3)$

All bifidobacteria isolates under the current study showed the ability to resist low ( $\mathrm{pH}=3$ ). After exposure for 3 hours, and growth was observed after incubation, the isolates showed high tolerance to bile salts in media containing these salts (Table 3). 
Table 3. Ability of Bifidobacterium isolates to tolerate low $(\mathrm{pH})$ and bile salts.

\begin{tabular}{lll}
\hline bile salts $\%$ 1 & $\mathbf{p H}=\mathbf{3}$ & B.breve \\
\hline+ & + & $\mathrm{b} 1$ \\
+ & + & $\mathrm{b} 2$ \\
+ & + & $\mathrm{b} 3$ \\
+ & + & $\mathrm{b} 4$ \\
+ & + & $\mathrm{BL}$ \\
+ & + & $\mathrm{BI}$ \\
\hline
\end{tabular}

\subsection{Determination MIC and MBC Values in Vitro}

The minimum inhibitory concentrations of CFE of LAB against MRSA at (50, 100,150 and 200) v/v of CFE as are shown in Table4. The inhibition of staphylococcal growth increases as the concentration of $\mathrm{b} 1, \mathrm{~b} 2, \mathrm{BL}$ and $\mathrm{BI}$ extract increases. Whereas b3 and b4 isolates have no MIC effect against methicillin-resistant Staphylococcus aureus was tested in the present study.
Table 4. Staphylococcal growth in different concentrations of cell-free extract of $L A B$.

\begin{tabular}{lllllll}
\hline & \multicolumn{6}{l}{ CFE addition volume $(\boldsymbol{\mu l})$ to $\mathbf{1 0}$ ml of broth } \\
\cline { 2 - 7 } LAB strains & $\mathbf{0}$ & $\mathbf{5 0}$ & $\mathbf{1 0 0}$ & $\mathbf{1 5 0}$ & $\mathbf{2 0 0}$ \\
& control & $\mathbf{5 0}$ & + & - & - & - \\
\hline b 1 & + & + & + & - & - \\
b 2 & + & + & + & + & + \\
b 3 & + & + & + & + & + \\
b 4 & + & + & - & - & - \\
BL & + & + & - & - & - \\
BI & + & & + & & & \\
\hline
\end{tabular}

$(+)$ visible growth appearance (turbid tube)

(-) no visible growth appearance (clear tube)

The results summarized in table (5) show that after $24 \mathrm{~h}$ at $37{ }^{\circ} \mathrm{C}$ incubation of MRSA with b1, BL and BI extracts, more than $99 \%$ of the MRSA bacteria were eliminated at concentration $(1.5 \%)$ of bifidobacterial CFE.

Table 5. Staphylococcal growth on subculture with three concentrations of LAB extraction.

\begin{tabular}{|c|c|c|c|c|c|c|c|c|c|c|c|c|c|}
\hline LAB strains & b 1 & & & b 2 & & & BL & & & BI & & & Control* \\
\hline Concentrations of & 1.0 & 1.5 & 2.0 & 1.0 & 1.5 & 2.0 & 1.0 & 1.5 & 2.0 & 1.0 & 1.5 & 2.0 & 0 \\
\hline CFE $\%$ of clear tubes & + & - & - & l & - & - & + & - & - & + & - & - & ++ \\
\hline
\end{tabular}

++ moderate growth + light growth - No growth / not tested

*tube inoculated with only MRSA cells (without CFE)

The MIC and MBC values obtained for extracts against the bacterial strains are summarized in table 6 . The strains b1, $\mathrm{BL}$ and $\mathrm{BI}$ observed equal values, whereas only b2 strain had no MIC value.

Table 6. Minimum inhibitory and minimum bactericidal concentration values of selected LAB extract on MRSA growth.

\begin{tabular}{lllllll|ll}
\hline $\begin{array}{l}\text { LAB } \\
\text { extract }\end{array}$ & b 1 & & b 2 & & BL & & BI & \\
\hline MRSA & MIC & MBC & MIC & MBC & MIC & MBC & MIC & MBC \\
growth & 1.0 & 1.5 & ND & 1.5 & 1.0 & 1.5 & 1.0 & 1.5 \\
\hline
\end{tabular}

$\mathrm{ND}=$ not detected

\section{Discussion}

After a series of isolation stages, pick 10 isolates of Bifidobacterium spp. from developing colonies on the MRSNNL medium isolating the bacteria of lactic acid which is characterized by its colonies on this medium [10],[17]

Sometimes, Bifidobacterium appear as a rod-like shape that tends to be clubbed with a branch to form a ' $\mathrm{Y}$ ' shape or irregular and this was documented by [18]. [17]

Since gram-positive strains were also catalase-negative, and unable to produce indole from tryptophan and gas from glucose as well as to reduce nitrogen, we assigned them to the Bifidobacterium genus. Identification of the isolated bifidobacterial strains to species was performed using API 20 A system applied specifically to anaerobic bacteria. The strains belong to B. breve, B. infantis and B. longum. [11, 1921].

For biochemical test, sugar fermentation (some variation exist between BI and BL), growth at different temperatures, ability to tolerate low $\mathrm{pH}$ and bile salts and finally forming deposit in bottom of broth media, the results of the current study matched with those of our previous study to be published, and these results are in agreement with other researchers [20-23].

Superbug" is a term invented by the media to describe bacteria that cannot be killed using multiple antibiotics. These bacteria are "antibiotic resistant" and have proven particularly problematic in healthcare settings where they increase the risk of worse clinical outcomes and death, a high percentage of hospital-acquired infections are caused by highly resistant bacteria, such as methicillin-resistant staphylococcus aureus (MRSA). People with MRSA are estimated to be 64 percent more likely to die than individuals with a non-resistant form of the infection [9].

A Lactic acid bacteria can produce antagonistic materials that vary in their spectra of activity. The antimicrobial agents from strains b1, BL, BI and b2 demonstrated a wide range and strong antimicrobial activity against MRSA. According to the study of [24] and our results, lactic acid bacteria can produce antimicrobials compounds and these bacteria exist in the gut of human infants.

Co-cultures of lactic acid strains with MRSA are used to demonstrate the potential of various probiotic bacteria to decrease the number and virulence of MRSA [6]. The inoculum concentration of the test strain extracts were 50 , 100,150 and $200 \mu \mathrm{l}(\mathrm{v} / \mathrm{v})$, and the inoculum concentration of MRSA was $(1 \%)$ of $10^{8} \mathrm{cfu} / \mathrm{ml}$. After intervals of culture incubation, the tubes were observed, turbid tubes indicated a negative result and the first clear tube was considered as MIC value. $\mathrm{LAB}$ produces many antimicrobial substances like organic acids, hydrogen peroxide and bacteriocins that inhibit 
other bacteria and fungi [25]. The CFSs of B.breve b1, b2, b3 and $\mathrm{b} 4, B$. infantis (BI) or B. longum (BL) were 4-fold concentrated, which were then used to determine the MICs of the test strains against MRSA.

Among the test strains, b1, BL and BI showed the strongest anti- MRSA activity (MIC $100 \mu \mathrm{l}$, MBC $150 \mu \mathrm{l}$ ), whereas b2 observed (MBC $150 \mu \mathrm{l})$. This result was not compared with other studies due to lack of similarity in the tested bacteria and CFE concentrations under the current study.

The difference in the anti-MRSA activity between the strains tested might be due to the nature of the antimicrobial compounds they produced [5]. The anti-MRSA activity of b1, BL, and BI may be mediated mainly by the organic acid production, i.e lactic acid and acetic acid. In fact, the decline in $\mathrm{pH}$ arising from the production of organic acid from LAB is a well-known factor to inhibit certain pathogenic strains. [6]

The MIC value of b2 extract was not detected with concentrations may be its MIC value located between 50 and $100 \mu \mathrm{l}$ of CFE concentration. The MIC and MBC values obtained for extracts against the bacterial strains varied among the three extracts. The MIC values corresponded well to the $\mathrm{MBC}$ values in $\mathrm{b} 1, \mathrm{BL}$ and $\mathrm{BI}$ extract in comparison with control; there were low and moderate differences of growth rate respectively (Table 7).

The inhibitory effect of Bifidobacterium in vitro was mainly due to the high acidity that resulted from the primary metabolic products of carbohydrate fermentation which include; lactic acid, hydrogen peroxide and other products. The acids produced by LAB enter into the sensitive bacterial cells and interfere with the necessary metabolic process such as substrate translocation and oxidative phosphorylation, and leads to decrease in the internal $\mathrm{pH}$ of bacterial cells [26]. There is also synergistic effect between lactic acid and acetic acid in the inhibitory effect of Bifidobacterium against some bacteria such as salmonella [10]. The mechanisms underlying Bifidobacterium inhibition of test bacteria may be due to presence many fractions containing proteins with a molecular mass below 5.000 $\mathrm{Da}$ and the finding of in vitro pointed to the peptideic nature of the Bifidobacterium linked to bacteria inhibition [27]. However, there are also reports of compounds of proteinaceous nature with antagonistic activity against all bacteria (these proteinaceous inhibitors target the cell membrane and depolarize it, and also inhibit synthesis of the cell wall. One of these peptides characterized as Bacteriocin is called Bifidocin B [26]. Diacetyl, hydrogen peroxide $\{\mathrm{H} 2 \mathrm{O} 2$ can have a strong oxidizing effect on membrane lipids and cellular proteins $\}$, organic acids such as lactic acid, acetic and propionic acids, the most documented kind of metabolites. [7] [28]. All of the reasons above give clear reasons for the high activity that was obtained in our results.

Another report showed that a mixture of bacteria isolated from the faeces of human breastfed infants containing $B$. bifidum was related to lowering of the $\mathrm{pH}$ level [29]. Another mechanism of action has been proposed as a $B$. infantis strain developed broad spectrum antimicrobial properties through the production of antimicrobial compounds, unrelated to acid production, which inhibited the growth of pathogens [30]. We have recently provided evidence that selected bifidobacterium strains isolated from human neonatal stools inhibit pathogens [31], [32]. Our results presented here and related to the antimicrobial activity of B.breve, B.longum and infant bifidobacterium strains are consistent with one of the mechanisms of action dependent on the production of antimicrobial compounds, as previously hypothesized. Indeed, we have provided evidence that the bactericidal activity of the strains b1, $\mathrm{BL}, \mathrm{BI}$ and $\mathrm{b} 2$ in vitro results from antimicrobial compounds present in the spent culture supernatants (in CFSs ), suggesting that they are secreted.

Non-dissociated form of, for example, lactic acid triggers to lower internal $\mathrm{pH}$ of the bacterial cell, which causes collapse in electrochemical proton gradient in sensitive bacteria, hence having a bacteriostatic or bactericidal effect [23] and [8]

\section{Conclusion}

Healthy breastfeeding infants from our study sites are potent sources of bifidobacteria (Friendly bacteria) isolates and these friendly bacteria have anti- MRSA activities in vitro especially when they grow as co-culture (CFSs) with the pathogens. The particular inhibitory metabolites are other than organic acids.

Anyway, the performed studies are of potential importance for the treatment of MRSA in vitro by determination the lowest concentration (MIC) of bifidobacterial extracts and then determine the bactericidal effect $(\mathrm{MBC})$ that kill the MRSA.

The studied strains of bifidobacteria of human origin (b1, $\mathrm{b} 2, \mathrm{~b} 3, \mathrm{~b} 4, \mathrm{BI}$ and $\mathrm{BL}$ ) can be considered promising as a basis for the development of probiotics as part of the alternative treatment of these serious multi-resistant strain, by ability to synthesize extracellular antimicrobial compounds that granted unfavourable conditions for growth of Staphylococcus aureus.

Finally, Bifidobacterium isolates conferred that it is the status of a probiotic bacterium with activity against MRSA in vitro

\section{References}

[1] Senok, A. C., Ismaeel A. Y and Botta, G. A. (2005) Probiotics: facts and myths. Clinical microbiology and infection. Volume 11, Issue 12.Pages 958-966.

[2] FAO/WHO. (2002). "Guidelines for the evaluation of probiotics in food. Report of a Joint FAO/WHO Working Group on Drafting Guidelines for the Evaluation of Probiotics in Food". London, Ontario, Canada.

[3] Mayo, B. (2010): Bifidobacteria: Genomics and molecular aspects (p. Xii 260). Norfolk, UK: Caister Academic. 
[4] Sagar, S., Morgan, M., Chen, S., Vos, A., Garssen, J., Bergenhenegouwen, J.,... Folkerts, G. (2014): Bifidobacterium breve and Lactobacillus rhamnosus treatment is as effective as budesonide at reducing inflammation in a murine model for chronic asthma. Respiratory Research Respir Res, 15(1), 4646. doi:10.1186/1465-9921-15-46.

[5] Bamidelea T. A., Adeniyib B. A.,. Ayenib F. A., Foworaa M. A. and Smitha S.I. (2013). The antagonistic activities of Lactic acid bacteria isolated from Nigerian salad vegetables against methicillin resistant Staphylococcus aureus. Global Research Journal of Microbiology Vol. 3(1) pp.18-23.

[6] Wysocki B. K' Bazo M, Smoragiewicz W. (2010)."Antibacterial activity of Lactobacillus acidophilus andLactobacillus casei against methicillin-resistant Staphylococcus aureus (MRSA).

[7] Georgievaa R, Yochevab L, Tserovskab L, Zhelezovab G, Stefanovaa N, Atanasovaa A, and et al (2015). Antimicrobial activity and antibiotic susceptibility of Lactobacillus and Bifidobacterium spp. intended for use as starter and probiotic cultures. Biotechnology \& Biotechnological Equipment, Vol. 29, No. $1,8491$.

[8] Lee J S, Chung M J and Seo J G. (2013). In Vitro Evaluation of Antimicrobial Activity of Lactic Acid Bacteria against Clostridium difficile. Toxicol. Res. Vol. 29, No. 2, pp.99-106.

[9] Antibiotic resistance: Skin infection prevention treatment helps battle 'superbugs' Written by Hannah Nichols Published: Sunday 31 July 2016

http://www.medicalnewstoday.com/articles/312008.php.

[10] AL-Saadi, Z. N. (2010). "Study of ability of Lactobacillus acidophilus and Bifidobacterium bifidum in the prevention and treatment for enteritis induced by Salmonella typhimurium in Rats. Ph.D. thesis". College of Education. Tikrit University.

[11] Buchanan R. E. and Gibbons S. E. (1974). Berge's Manual of Determinative Bcteriology. $8^{\text {th }}$ ed. Williams and Wilkins. Baltimore Maryland, USA.

[12] Buck LM, Gilliland SE (1994). Comparison of freshly isolated strains of Lactobacillus acidophillus of human intestinal origin for ability to assimilate cholesterol during growth. J. Dairy Sci., 77: 2925-2933.

[13] Fuller R. (1989). "Probiotics in man and animals". J Appl Bacteriol 66(5): 365-378.

[14] Harrigan, W. F and McCance, M. E. (1976). Laboratory Methods in Food and Dairy Microbiology, second ed. Academic Press, London.

[15] Clinical and Laboratory Standards Institute (2010): Performance Standards for Antimicrobial Susceptibility Testing; Twentieth Informational Supplement, M100-S20.

[16] Alzubaid Zainab M. Alzubaidy. Shean I. Kakey Jassim F. Ali (2013) Antibacterial Effects of Lactic Acid Bacteria Cell Free Extract on the Growth of Local Isolates of Listeria moncytogenes from some Food Sources.

[17] Wasilewska E. and Bielecka M. (2003). ISOLATION AND IDENTIFICATION OF BIFIDOBACTERIA FROM INFANT GUT. Pol. J. Food Nutr. Sci. Vol. 12/53, SI 1, pp. 90-94.

[18] Rita Narayanan, B.Suresh Subramonian, T. R. Pugazhenthi. (2013). "Isolation of Bifidobacteria from Infant Faeces Vol (3), 2250-1991.
[19] Mikkel Jungersen, Anette Wind, Eric Johansen, Jeffrey E. Christensen, Birgitte Stuer-Lauridsen, and Dorte Eskesen (2014). The Science behind the Probiotic Strain Bifidobacterium animalis subsp. Lactis, 92-110; doi: 10.3390 .

[20] Kawasaki, S., T. Mimura, T. Satoh, K. Takeda, and Y. Niimura. (2006). "Response of the microaerophilic Bifidobacterium species", B. boum and B. thermophilum, to oxygen. Appl. Environ. Microbiol. 72:6854-6858.

[21] Zinedine A. and Faid M. (2007). Isolation and Characterization of Strains of Bifidobacteria with Probiotic Proprieties In vitro. World Journal of Dairy \& Food Sciences 2 (1): 28-34.

[22] Kail A Kail Asapathy and James Chin, (2007). "Survival and therapeutic potential of probiotic organisms with reference to Lactobacillus acidophilus and Bifidobacterium spp., 78, 80-88.

[23] Borja Sa'nchez, Marie-Christine Champomier-Verge 'Mar'a del Carmen Collado,et al., (2007 ) Low-pH Adaptation and the Acid Tolerance Response of Bifidobacterium longum Biotype longum. APPLIED AND ENVIRONMENTAL MICROBIOLOGY, Vol. 73, No. 20, p. 6450-6459.

[24] Amin M, Sheikh A.F., Goodarzi H. and Sormeh M. (2013). Identification of Bifidobacterium animalis, Bifidobacterium adolescentis and Bifidobacterium bifidum from Stool of Children and Detection of Their Antibacterial Properties. Advances in Infectious Diseases, 3, 200-204.

[25] Denkova, R. V. Yanakieva, Z. Denkova, V. Nikolova \& V. Radeva, (2013). In vitro inhibitory activity of Bifidobacterium and Lactobacillus strains against Candida albicans. Bulg. J. Vet. Med., 16, No 3, 186-197.

[26] Mohsen, Y. M. B., Shawket, D. S. and Abd-Alsattar,D. (2013). NOVEL PROBIOTIC BIFIDOBACTERIUM OVERCOMES SYNERGISTIC EFFECT OF THREE NATURALBIOTIC OMNI DRUG AND ANTIBIOTIC AGAINST SOME UTI PATHOGENS. I.J.S.N., VOL. 4(3):456-462.

[27] Chenoll E., Casinos B., Bataller E., Astals P., Echevarría J., Iglesias J. R., et al. (2011). Novel probioticBifidobacterium bifidum CECT 7366 strain active against the pathogenic bacterium Helicobacter pylori. Appl. Environ. Microbiol. 77 1335-1343. 10.1128 .

[28] Hor, Y. Y. and Liong, M. T.(2014). Use of extracellular extracts of lactic acid bacteria and bifidobacteria for the inhibition of dermatological pathogen Staphylococcus aureus. Dermatologica Sinica. 32: 141-147.

[29] Hentges DJ, Marsh WW, Petschow BW,et al (1995). Influence of a human milk diet on colonization resistance mechanisms against Salmonella typhimurium in human faecal bacteriaassociated mice. Microb Ecol Health Dis; 8: 139-49.

[30] Gibson GR,Wang W.(1994).Regulatory effects of bifidobacteria on the growth of other colonic bacteria.J Appl Bacteriol; 77:412-20

[31] Bernet M-F, Brassart D, Neeser JR, et al. (1993). Adhering bifidobacterial strains inhibit interactions of enteropathogens with cultured human intestinal epithelial cells. Appl Environ Microbiol; 59: 4121-8.

[32] Liévin V, PeiVer I, Hudault S, Rochat F, Brassart D, Neeser JR, Servin A L (200 ) Bifidobacterium strains from resident infant human gastrointestinal microflora exert antimicrobial activity. Gut;47:646-652646. 